Service social

\title{
La revue Service social a quarante ans!
}

\section{Simone Paré}

Volume 40, numéro 1, 1991

Éthique et intervention sociale

URI : https://id.erudit.org/iderudit/706510ar

DOI : https://doi.org/10.7202/706510ar

Aller au sommaire du numéro

Éditeur(s)

École de service social de l'Université Laval

ISSN

1708-1734 (numérique)

Découvrir la revue

Citer cet article

Paré, S. (1991). La revue Service social a quarante ans! Service social, 40(1), 3-4. https://doi.org/10.7202/706510ar d'utilisation que vous pouvez consulter en ligne.

https://apropos.erudit.org/fr/usagers/politique-dutilisation/ 


\section{ÉDITORIAL}

\section{La revue Service social a quarante ans !}

En 1945, à l'incitation du père Georges-Henri Lévesque, o.p., fondateur de la Faculté des sciences sociales de l'Université Laval, I'École de service social ouvrait ses portes à un premier groupe de futurs travailleurs sociaux. Le père Lévesque confia la direction de cette école à un Franciscain, le père Gonzalve Poulin. Celui-ci était un ardent homme d'études et d'action, entreprenant, rempli d'idées nouvelles et féru d'histoire. Il eut vite fait, à la suite de l'organisation des premiers cours et stages en service social, de souhaiter la création d'une revue qui serait l'organe d'expression de la nouvelle école. Ainsi parut, en avril 1951, le premier numéro de Service social. Pour montrer la quasi-universalité de la profession en question, on peut citer les sujets et sciences traités dans ce premier numéro : sciences sociales, théologie, communauté politique, médecine, lois et cour de bien-être social, et même génie forestier et recherche folklorique. Comme quoi I'histoire humaine tout entière ne saurait laisser le service social indifférent. Ses tenants ouvrirent même un premier centre social pour groupes en 1947, tandis que M. de Hayda Denault avait déjà fondé en 1945 le Service familial de Québec pour la pratique du service social personnel.

Le "règne " du père Poulin sur la revue dura de 1951 à 1960 et Simone Paré lui succéda comme directrice et éditrice de 1960 à 1982. La revue passa ensuite successivement sous la responsabilité de Jocelyn Lindsay et Jean-Louis Gendron, qui en est encore le directeur.

La satisfaction que nous éprouvons tous à célébrer ce quarantième anniversaire nous fait anticiper avec joie le jubilé d'or de la revue qui sera fêté en I'an 2001 ! Longue vie à ses fidèles responsables et bon succès à ceux qui appliquent les théories et pratiques dont ils se réclament.

Simone Paré 


\section{N.D.L.R.}

À l'occasion du $40^{\mathrm{e}}$ anniversaire de Service social, nous avons demandé à celle qui en fut la directrice pendant plus de vingt ans de nous rappeler les origines de la revue. Cette aimable contribution de Simone Paré se veut un hommage à tous ceux et celles qui ont fait de Service social la revue qu'elle est devenue, quarante ans plus tard.

Merci à toutes ces personnes !

$$
\text { Jean-Louis Gendron }
$$

